on the council in 1888 and in subsequent years, and for a time as vice-president.

His attention was in 1887 attracted to the geology of the Lizard, and there his observations led him to maintain the igneous origin of many of the foliated crystalline rocks. He dealt also with the granite of Dartmoor, and showed that it presented the ordinary features of an intrusive igneous rock.

In I894 he was elected president of the Geologists' Association for the usual two years, and in his addresses he summarised the results of some of his Indian work. He sought to dispel the popular notion that the Himalayas were upraised in late Tertiary times-they had, of course, a pre-Tertiary history, although there was a general absence of crushing and contortion prior to the Miocene, and these disturbances were due to the intrusion of the gneissose granite.

General McMahon was elected a fellow of the Royal Society in 1898 , and in the following year the Lyell medal was awarded to him by the Geological Society. The president (Mr. Whitaker), in addressing him on that occasion, remarked, "Labouring under the disadvantage of taking to the study of geology comparatively late in life, you have attacked it with the energy of a British soldier, and have fought your way into the foremost rank of our petrologists."

In 1902 he contributed to the Geological Magazine (with Mr. Hudleston) an important paper on the fossils from the Hindu Khoosh. In the autumn of the same year he took duty as president of Section $\mathrm{C}$ of the British Association at Belfast. Since that date his health had gradually declined, and he died from heart failure on February 2r. Personally he was endeared to all who knew him by his sterling character and by his genial and courteous nature.

H. B. W.

\section{THE NEW EDUCATION AUTHORITY FOR} LONDON.

$\mathrm{WT}^{\mathrm{E}} \mathrm{E}$ have received the following memorial referring to the proposed constitution of the Education Committee for London. An article upon the scheme adopted by the London County Council appeared in our issue of February II.

To the Secretary of the Board of Education. Sir, February 22, 1904.

Having carefully considered the scheme proposed by the London County Council for the constitution of its Education Committee, which has been submitted for the approval of your Board, we, without bias towards any political party, desire to draw the attention of your Board to certain defects in the scheme which must seriously impair the efficiency of the committee in its work of coordinating and developing all varieties of education in London.

The Education Committee will have to undertake not only the work of elementary instruction hitherto carried out by the School Board, but it will also have the more difficult task of supplying and aiding the supply of secondary, technical, and higher education, and of promoting the coordination of all forms of education in London. 'The present backward educational position of this country is especially marked in those branches designated "secondary" and "higher." To develop the resources of London in these respects, to raise the standard of secondary education, to provide for the training of teachers for both primary and secondary schools, to organise and support the facilities for university training, and finally to organise a great technical high school in the university and the more strictly technical instruction of the polytechnics, so that the whole may be one educational edifice crowned by the University of London, will be a task of great magnitude, and will require the assistance of persons specially skilled in and acquainted with the needs and conditions of these various grades of education.

Under the scheme sent in by the County Council, it seems NO. I792, VOL. 69] to us that no guarantee is afforded that the Council will' have at its disposal any sufficient number of persons of experience in education and acquainted with the needs of the various kinds of schools in London. We would therefore urge on the Board of Education the desirability of amending the scheme so that the Education Committee may include persons who would be universally recognised as authorities on the needs of the university, the technical institutes, and the elementary and secondary schools.

While trusting that the Board of Education will take all possible means to secure the improvement of the scheme along the lines indicated above, we would earnestly deprecate any action of the Board that would lead to the postponement of the appointed day, on which, by the provisions of the Education Act, the administration of a unified system of education for London is to begin.

We have the honour to remain, Sir, Your obedient Servants,

(Signed),

List of Signatures.

Dr. W. H. Allchin, senior physician to the Westminster Hospital, member of the Senate of the University of London; Dr. Henry E. Armstrong, F.R.S., professor of chemistry, Central Institute of City and Guilds; Right Hon. Lord Avebury, F.R.S., president of the Associated Chambers of Commerce; Sir J. Wolfe Barry, chairman of Executive Committee, City and Guilds Institute; Dr. Horace $T$. Brown, F.R.S.; Sir Lauder Brunton, F.R.S.; Dr. Henry $T$. Butlin, Dean of the Faculty of Medicine of the University of London; Prof. D. S. Capper, professor of mechanical engineering, King's College; Sir William Crookes, F.R.S.; Prof. Hugh L. Callendar, professor of physics, Royal College of Science; Mr. R. F. Charles, chairman of the Central Branch of the Teachers' Guild; Sir W. S. Church, Bart., president of the Royal College of Physicians; Prof. J. D. Cormack, professor of mechanical engineering, University College; Prof. G. Carey Foster, F.R.S., principal of University College, London; Mr. J. Easterbrook, headmaster of Owen's School, Islington; Prof. Ernest A. Gardner, professor of archæology, University College; Mr. Herbert B. Garrod, General Secretary of the Teachers' Guild; Sir William R. Gowers, F.R.S.; Prof. W. D. Halliburton, F.R.S., professor of physiology, King's College; Prof. M. J.' M. Hill, F.R.S., professor of mathematics, University College, London; Rev. Arthur C. Headlam, principal of King's College, London; Sir Henry G. Howse, member of Senate of London University; Prof. W. P. Ker, professor of English, University College; Dean of the Faculty of Arts, University of London; Sir Norman Lockyer, K.C.B., F.R.S., president of the British Association; Sir Philip Magnus, fellow and member of Senate of University of London; Dr. Charles J. Martin, F.R.S., director of the Lister Institute of Preventive Medicine; Rev. $J$. Arbuthnot Nairn, headmaster of the Merchant Taylor's School; Prof. Karl Pearson, F.R.S., professor of applied mathematics, University College; Sir E. C. Perry, member of Senate, London University; Prof. John Perry, F.R.S. professor of mathematics, Royal College of Science; Sir William Ramsay, K.C.B., F.R.S., professor of chemistry, University College, London, president of the Society of Chemical Industry; Sir Owen Roberts; Dr. R. P. Scott, Incorporated Association of Head Masters; Mrs. S. T. D. Shaw, late lecturer at Newnham College, and at the Training College for Secondary Teachers; Dr. H. J. Spencer, headmaster of University College School; Prof. E. H. Starling, F.R.S., professor of physiology, University College; Miss L. M. Strong, head mistress of Baker Street High School for Girls; Dr. T. E. Thorpe, C.B., F.R.S., director of Government Laboratories, London; Prof. William A. Tilden, F.R.S., Dean of the Faculty of Science, University of London, president of the Chemical Society; Prof. Fred. T. Trouton, F.R.S., professor of physics, University College; Dr. John Tweedy, president of the Royal College of Surgeons; Dr. A. D. Waller, F.R.S., director of the physiological laboratory, University of London; Sir W. H. White, K.C.B., F.R.S., president of the Institution of Civil Engineers; Sir H. T. Wood, secretary, Society of Arts; Mrs. E. Woodhouse, head mistress of the Clapham High School. 